\title{
ANALISIS DAMPAK FAKTOR MAKRO EKONOMI PADA SAHAM JAKARTA ISLAMIC INDEX
}

\author{
Moh. Faizin 1 \\ Nurul Rizki Oktawati ${ }^{2}$
}

\author{
IAIN Ponorogo, Jawa Timur, Indonesia ${ }^{1,2}$ \\ E-mail: faiziniainpo@gmail.com ${ }^{1,2}$
}

\begin{abstract}
The Indonesian economy is expected to increase by increasing the role of the capital market, because it provides an alternative for the company's funding needs to increase business, which in turn will also have an impact on the increase in people's welfare. Islamic economics are economic principles derived from the Al-Quran and Sunnah. Economic development should be carried out in accordance with sharia principles in every place and time of the Jakarta Islamic Index totaling 30 shares of sharia-based companies. From the macroeconomic level, the quantity $/$ amount of money in circulation, the exchange rate (exchange rate), inflation, and interest rates can have an effect on stock price fluctuations. This study aims to analyze the impact of macroeconomic variables on the JII stock index. This study uses secondary data and observation methods for the period 2010 to 2019. Eviews 9 software is used for analysis. By using the VECM model, it is known that the results show that the long-term relationship, the inflation variable, the exchange rate and the money supply (JUB) are able to significantly influence the JII price index. Short-term estimation results between variables. Only the inflation and exchange rate variables have a significant effect on the JII price index.
\end{abstract}

Keywords: stoc; exchange rate; inflation; money and interest rate.

\begin{abstract}
ABSTRAK
Ekonomi Indonesia diharapkan mengalami peningkatan dengan meningkatkan peran pasar modal, karena memberikan alternatif kebutuhan dana perusahaan untuk peningkatan usaha yang pada akhirnya juga berdampak naiknya kesejahteraan masyarakat. Ekonomi Islam adalah kaidah-kaidah ekonomi yang bersumber dari Al-Quran dan Sunah. Pembangunan ekonomi hendaknya dilakukan sesuai kaidah syariah di setiap tempat maupun waktu Jakarta Islamic Index berjumlah 30 saham perusahaan yang berbasis syariah. Dari tingkat ekonomi makro, kuantitas/jumlah uang yang beredar, nilai tukar (kurs), inflasi, dan suku bunga dapat memberi efek pada fluktuasi harga saham. Penelitian ini bertujuan menganalis dampak variabel makro ekonomi pada indeks saham JII. Penelitian ini menggunakan data sekunder, dan metode observasi untuk periode 2010 sampai 2019. Software Eviews 9 digunakan untuk analisis. Dengan menggunakan model VECM diketahui bahwa Hasil penelitian menunjukkan bahwa hubungan jangka panjang, variabel inflasi, kurs dan jumlah uang yang beredar (JUB) yang mampu mempengaruhi secara signifikan terhadap indeks harga JII. Hasil estimasi jangka pendek antar variabel. Hanya variabel inflasi dan kurs yang berpengaruh secara signifikan terhadap indeks harga JII.
\end{abstract}

Kata kunci: saham, kurs, inflasi, uang dan suku bunga. 


\section{PENDAHULUAN}

Ekonomi Indonesia diharapkan mengalami peningkatan dengan meningkatkan peran pasar modal, karena memberikan alternatif kebutuhan dana perusahaan untuk peningkatan usaha yang pada akhirnya juga berdampak naiknya kesejahteraan masyarakat (Septifany, 2015). Ekonomi Islam adalah kaidah-kaidah ekonomi yang bersumber dari Al-Quran dan Sunah. Pembangunan ekonomi hendaknya dilakukan sesuai kaidah syariah di setiap tempat maupun waktu (Meirison, 2017).

Kinerjanya perdagangan saham syariah dapat diketahui dengan cara melihat saham-saham JII atau Jakarta Islamic index. Hingga saat ini jumlah anggota JII sebanyak 30 perusahaan. Secara umum semua investor saham syariah, juga berharap mendapatkan keuntungan (return) yang didapatkan dari selisih kenaikan ataupun penurunan nilai saham. Dalam perdagangan saham, kinerja perdagangan saham tak bisa lepas dari peran bank sentral (Bank Indonesia) dan pemerintah dalam pelaksanaan tugasnya menjaga setabilnya kondisi ekonomi nasional. Kondisi makro ekonomi ini menjadi sangat penting mengingat di setiap periodenya variabel-variabel tersebut terus menerus mengalami fluktuasi, diantara variabel tersebut adalah naik turunya kus atau nilai tukar, fluktuasi inflasi, banyaknya uang yang ada di masyarakat serta acuan sukus bunga yang dikeluarkan BI. Hal ini menjadi alasan bahwa variabel-variabel dapat memberi efek naik turunnya harga saham, termasuk indek JII juga akan terpengaruh.

Ketika mata uang dalam negeri mengalami penguatan (terapreassiasi) atau sebaliknya mengalami pelemahan (terdepresiasi) hal ini menunjukan kondisi 
ekonomi negara membaik atau memburuk. Kestabilan nilai kurs mata uang dianggap penting mengingat perusahan yang aktif dalam kegiatan ekspor ataupun impor. Karena kegiatan ekspor impor menggunakan Dolar Amerika sebagai alat pembayaran, naik turunnya kurs dolar terhadap rupiah akan menimbulkan dampak kepada saham perusahaan di pasar modal. Ketika rupiah melemah, harga bahan baku impor menjadi mahal, permasalahan ini akan sangat berefek terhadap perusahaan, mengingat beban produksi yang mengalami kenaikan. Kenaikan beban produksi akan mengurangi keuntungan perusahan, akibatnya nilai harga saham menjadi turun karena kurang diminati para investor.

Faktor berikutnya adalah inflasi, (Sukirno, 2004) menyatakan bahwa inflasi berarti fenomena naiknya harga-harga barang dan jasa akibat permintaan pasar cenderung lebih besar dari penawaran. (Pradana, 2018) mempunyai pendapat yang senada dengan (Samuelson, 2004) bahwa harga barang dan jasa yang naik akibat inflasi dalam waktu yang lama dan terjadi secara umum. Hal ini menjadi alasan bahwa kenaikan atas satu barang saja bukan merupakan sebuah fenomena inflasi. Kenaikan harga pada musim tertentu, atau mendekati hari besar juga tidak bisa kategorikan inflasi, sehingga tidak perlu kebijakan khusus untuk menanggulanginya. Inflasi dianggap dapat memberi efek harga saham. Kenaikan inflasi akan berdampak pada menurunnya return saham bagi para investor (Geriadi \& Wiksuana, 2017). Ketika terjadi inflasi ditengah masyarakat, apabila tidak ada kenaikan pendapatan, akan berdampak pada lesunya kegiatan ekonomi akibat menurunnya daya beli (Sitinjak, 2016). Gejala inflasi berupa kenaikan harga barang dan jasa nantinya berefek pada kenaikan atas biaya modal dalam 
suatu kegiatan investasi. Permasalahan ini menjadi lebih pelik akibat pada sektor riil terjadi penurunan daya beli di masyarakat.

Dampak berikutnya akan dirasakan oleh perusahaan berupa menurunnya laba perusahaan akibat menurunnya jumlah permintaan di masyarakat. Penerimaan laba yang turun, berakibat pada menurunnya harga saham. Tingginya inflasi berdampak pada jatuhnya harga saham, sebaliknya inflasi terlalu rendah menjadikan pasar saham menjadi lesu (Utami \& Herlambang, 2017). Kewajaran uang yang beredar di masyarakat akan berdampak positif pada arus perdagangan di pasar saham. Hal ini menjadi indikator pada peningkatan ekonomi. Kondisi ini menjadikan masyarakat untuk cenderung berani dalam melakukan investasi, dampak selanjutnya indeks harga saham juga mengalami peningkatan.

Faktor fundamental makro ekonomi berikutnya adalah tingkat bunga. Kebijakan penetapan suku bunga nantinya diharapkan bisa berdampak pada perekonomian. Kebijakan suku bunga bertujuan untuk menguatkan operasi moneter yang dilakukan BI. Selain berfungsi untuk mempengaruhi suku bunga pasar dalan industri perbankkan maupun industri keuangan yang lain, kebijakan suku bunga bank sentral juga merupakan sinyal atas penguatan moneter pada pasar keuangan. Suku bunga yang mengalami kenaikan akan berdampak pada terjadinya perpindahan instrumen investasi dari saham ke deposito bank. (Fathurrahman \& Rusdi, 2019) menjelaskan bahwa tingginya suku bunga merupakan sinyal tidak baik bagi harga saham, sebab naiknya suku bunga akan menaikkan tabungan masyarakat.

Hasil penelitian yang dilakukan beberapa orang memperlihatkan 
perbedaan, misalnya penelitian (Utami \& Herlambang, 2017) didapatkan bahwa kurs dan suku bunga memberi efek naik turunnya harga saham, sementara inflasi tidak terdapat efek. Berbeda dengan penelitian (Nofiatin, 2013), hanya kurs yang berefek, sementara variabel inflasi serta variabel suku bunga keduanya tidak mempunyai efek. Hasil penelitian (Sunardi \& Ula, 2017), (Ridha \& Harmaini, 2019) didapatkan bahwa kenaikan atau penurunan atas suku bunga dan inflasi berefek negatif pada harga saham, sementara variabel kurs tidak berdampak. Sementara hasil penelitian yang dilakukan (Suriyani \& Sudiartha, 2018), harga saham hanya dipengaruhi oleh kurs secara signifikan, sementara variabel yang lain tidak.

Penelitian terdahulu telah banyak dilakukan terkait faktor makro ekonomi yang dianggap memberi efek pada harga saham, tetapi hasil penelitian tersebut belum dapat memperlihatkan hasil yang konsisten. Berdasarkan latar belakang tersebut, penulis meneliti tentang analisis dampak faktor makro ekonomi pada saham Jakarta Islamic Index.

\section{METODE PENELITIAN}

Pendekatan kuantitatif digunakan dalam penelitian ini. Data skunder yang digunakan. mulai Januari 2010 s/d Desember 2019 dan bertempat di Indonesia. Variabel yang digunakan terdiri dari data kurs, laporan bulanan inflasi, jumlah uang beredar (M2) serta data suku bunga acuan BI, serta indeks JII. Sementara instrumen dan teknik pengumpulan data tidak ada, karena data sudah tersedia.

Teknik Analisis. Metode analisis data yang dilakukan dalam penelitian 
ini terdapat beberapa tahapan. Hal ini dilakukan mengingat dalam penelitian ini menggunakan data time series (runtut waktu). Sebelum dilakukan pengujian data lebih lanjut, data time series harus dipastikan sudah dalam keadaan stasioner. untuk pengujian data stasioner ini dilakukan dengan menggunakan uji ADF. Pada tahap awal data diuji pada keadaan data level. Dengan memperhatikan nilai pada probabilitas hasil uji ADF akan dapat diketahui apakah data tersebut sudah stasioner apa belum. Apabila nilai probabilitas kurang dari 5\%, maka data dianggap stasioner, tetapi apabila nilai probabilitas diatas $5 \%$ maka perlu dilakukan pengujian lebih lanjut pada kondisi $1^{\text {st }}$ difference, pengujian ini dilakukan hingga didapat hasil data yang sudah stationer untuk menghindari estimasi model yang baik dan tidak lancung.

Penentuan lag optimal diperlukan untuk menghasil hasil estimasi pada model akan dapat menjelaskan secara efisien, dinamis serta komprehensif. Lap optimal dalam hal ini bisa dikatakan tidak terlalupanjang ataupun terlalu pendek. Pemilihan lag yang terlalu panjang dapat menjadikan hasil pengukuran model menjadi tidak efisien, begitu pula apabila lag yang dipilih terlalu pendek akan berdampak pada hasil penghitungan model menjadi tidak dinamis.

Pemilihan lag optimal dalam penelitian ini dilakukan dengan menggunakan uji Lag Length Criteria. Tahap berikutnya setelah pemilihan lag yang optimal, maka dilakukan uji stabilitas, uji stabilitas berguna untuk memastikan model dalam VAR atau VECM yang terbentuk dapat stabil.

Perbedaan model VAR dan VECM terletak pada hasil uji kointegrasi. Apabila hasil menunjukkan bahwa terdapat hubungan kointegrasi pada sebagian 
besar atau keseluruhan variabel, maka model yang terpilih adalah VECM. Pengujian kointegrasi dilakukan dengan uji JCT (Johansen Cointegration test). Pengujian tahap selanjutnya yaitu dengan melihat hubungan kausalitas antar variabel. dengan menggunakan uji kausalitas Granger, akan dapat dilihat apakah dari masing-masing variabel dapat berperan menjadi variabel dependen antara satu variabel dengan variabel yang lain.

Hasil estimasi uji kointegrasi apabila didapati antar variabel terdapat kointegrasi, maka model yang terpilih adalah model VECM. Pada model VECM terdapat teknik peramalan IRF dan VD. Pada IRF (Impulse Response Function) dilakukan dengan tujuan untuk melihat/meperkirakan efek terjadinya guncangan yang disebabkan salah satu variabel terhadap variabel lainnya. Sementara VD (Variance Decompotition) digunakan untuk mengetahui nilai seberapa besar kontribusi pada tiap periode baik dari variabel itu sendiri maupun variabel yang lain.

\section{HASIL DAN PEMBAHASAN}

Tahap awal setelah dilakukan pengolahan data adalah dengan mendeskrpsikan data dengan menggunakan analisis dekriptif. Hasil analisis deskriptif dari variabel terdiri dari variabel kurs, inflasi, jumlah uang yang bereda dan suku bunga, serta nilai harga saham JII dapat dilihat pada Tabel 1.

Tabel 1.

\section{Hasil Analisis Deskriptif}

\begin{tabular}{lrrrrr}
\hline Variabel & N & Minimum & Maximum & \multicolumn{1}{c}{ Mean } & Std. Deviation \\
\hline INFLASI & 120 & 2.48 & 8.79 & 4.8118 & 1.67838 \\
BI 7-DAY RR & 120 & 4.25 & 7.75 & 6.1688 & 1.03111 \\
KURS & 120 & 8032.00 & 15178.87 & 11553.7862 & 2344.43556
\end{tabular}




\begin{tabular}{lrrrrr} 
JUB & 120 & 2066.48 & 6136.50 & 4049.7298 & 1238.98919 \\
JII & 120 & 413.73 & 787.12 & 630.2753 & 85.17167 \\
Valid N (listwise) & 120 & & & & \\
\hline
\end{tabular}

Sumber: Data diolah, 2020

Hasil pengolahan data pada Tabel 1 menunjukkan deskriptif dari keempat variabel. dapat diketahui bahwa penelitian menggunakan sampel jenuh, dimana keseluruhan dari populasi digunakan dalam penelitian sebagai sampel. Jumlah populasi yang digunakan sebanyak 120. Dari penyajian tabel diketahui bahwa nilai minimum inflasi yang terjadi sebesar $2,48 \%$ serta mengalami nilai inflasi tertinggi (maksimum) sebesar 8,79\%. Sementara untuk nilai suku bunga minimum adalah sebesar $4,25 \%$ dan nilai aksimum dari suku bunga sebesar 7,75\%. Pada periode pengamatan sejak 2010 s/d 2019 data menunjukkan bahwa nilai kurs minimum sebesar Rp. 8.032 dan nilai kurs maksimum sebesar Rp. 15.178. Sementara pada jumlah uang beredar menunjukkan nilai minimum sebesar Rp. 2.066,48 T dan nilai maksimum sebesar RP. 6.136,50 T. Begitu pula pada nilai dari Jakarta Islamic Index, nilai minimum sebesar 413,73 dan nilai maksimum sebesar 787,12. Nilai rata-rata masing-masing kelima variabel menunjukkan menunjukkan angka yang lebih tinggi dari nilai stadar deviasi. Hal ini mengindikasikan bahwa sebaran data tersebar secara normal dan baik.

Uji unit root atau stasioner dilakukan sebelum data dilakukan estimasi model. Hasil pengujian di tunjukan pada tabel 2. Penjelasan dari tabel menunjukkan bahwa pada data level menunjukkan hasil pengujian data masih belum stasioner. hal ini dapat diketahui dari nilai probabilitas yang masih diatas 
0,05. Hasil data level kemudian dilakukan uji stasioner kembali pada kondisi $1^{\text {st }}$ difference. Pada kondisi $1^{\text {st }}$ difference data menunjukkan hasil sudah stasioner. Hal ini diketahui dari besarnya nilai probabilitas yang lebih kecil dari 0,05.

Tabel 2

Hasil Uji Stasioner

\begin{tabular}{|c|c|c|c|c|}
\hline \multirow[b]{2}{*}{ Method } & \multicolumn{2}{|c|}{ Data level } & \multicolumn{2}{|c|}{$1^{\text {st }}$ difference } \\
\hline & Statistic & Prob.** & Statistic & Prob.** \\
\hline \multicolumn{5}{|c|}{ Null: Unit root (assumes common unit root process) } \\
\hline Levin, Lin \& Chu $t^{*}$ & 0.02799 & 0.5112 & -24.1538 & 0.0000 \\
\hline \multicolumn{5}{|c|}{ Null: Unit root (assumes individual unit root process) } \\
\hline Im, Pesaran and Shin W-stat & 0.42891 & 0.6660 & -20.8613 & 0.0000 \\
\hline ADF - Fisher Chi-square & 9.36278 & 0.4981 & 287.198 & 0.0000 \\
\hline PP - Fisher Chi-square & 7.85653 & 0.6428 & 289.204 & 0.0000 \\
\hline
\end{tabular}

Tahap selanjutnya setelah diketahui bahwa data sudah stasioner, maka dilakukan pemilihan lag optimal. Pemilihan lag optimal dilakukan dengan menggunakan Lag Order Selection Criteria. Pada tabel 3, hasil pengujian diketahui bahwa lag optimal pada kondisi data $1^{\text {st }}$ difference berada pada lag 1 . Hal ini dapat dilihat dari banyaknya tanda bintang pada masing-masing lag yang ada. Pemilihan lag optimal bertujuan untuk mengetahui keterkaitan dari masingmasing variabel dalam estimasi model. Penjelasan terkait pemilihan lag yang teramat kecil berdampak pada model menjadi tidak mampu menjelaskan hubungan antar variabel, smentara lag yang teramat besar menjadikan kemampuan model dalam menjelaskan menjadi tidak efisien.

\section{Tabel 3}

Hasil Uji Lag Optimal

\begin{tabular}{ccccccc}
\hline \multicolumn{6}{c}{ variables: D(INFLASI) D(BIRATE) D(KURS) D(JUB) D(JII) } \\
Lag & LogL & LR & FPE & AIC & SC & HQ \\
\hline 0 & -2041.539 & NA & $1.07 e+09$ & 34.98358 & $35.10162^{*}$ & $35.03150^{*}$ \\
1 & -2008.323 & $63.02545^{*}$ & $9.33 \mathrm{e}+08^{*}$ & $34.84313^{*}$ & 35.55138 & 35.13067 \\
2 & -1992.384 & 28.88222 & $1.09 \mathrm{e}+09$ & 34.99801 & 36.29647 & 35.52517 \\
\hline \multicolumn{7}{l}{ Sumber: Data diolah, 2020}
\end{tabular}


Tahap berikutnya setelah diketahui lag optimal, maka selanjutnya harus dipastikan bahwa kondisi model dalam keadaan stabil. Pengujian ini dilakukan dengan uji stabilitas. Pengujian ini berguna agar estimasi model dalam menjelaskan benar-benar valid. hasil pengujian untuk uji stabilitas dapat dilihat pada tabel 4. Hasil menunjukkan bahwa pada kolom nilai modulus, nilai menunjukkan angka dibawah 1, sehingga data dianggap stabil dan dapat dilanjutkan untuk proses berikutnya.

\section{Tabel 4}

Hasil Uji Stabilitas

\begin{tabular}{ll}
\hline Root & Modulus \\
\hline 0.434545 & 0.434545 \\
0.211285 & 0.211285 \\
$-0.125252-0.129317 \mathrm{i}$ & 0.180030 \\
$-0.125252+0.129317 \mathrm{i}$ & 0.180030 \\
0.114221 & 0.114221 \\
\hline
\end{tabular}

Sumber: Data diolah, 2020

Tahap yang dilakukan selanjutnya berupa penentuan model. penentuan model antara menggunakan model VAR ataupun menggunakan model VECM dilakukan melihat hasil uji kointegrasi. Ketika hasil uji kointegrasi menunjukkan bahwa sebagian besar atau keseluruhan variabel terdapat kointegrasi maka model yang tepat adalah menggunakan model VECM, sebaliknya apabila hasil menunjukkan bahwa dari setiap variabel tidak menunjukkan hubungan kointegrasi, maka model yang paling tepat untuk dipilih adalah model VAR. hasil uji kointegrasi dapat dilihat pada tabel 5. Hasil uji kointegrasi menujukkan bahwa dari kesemua variabel menunjukkan terdapat hubungan kointegrasi, sehingga model yang dipilih adalah model VECM. Hal ini disimpulkan dari banyaknya 
tanda bintang yang ada pada tabel

Tabel 5

Hasil Uji Kointegrasi

\begin{tabular}{ccccc}
\hline $\begin{array}{c}\text { Hypothesized } \\
\text { No. of CE(s) }\end{array}$ & Eigenvalue & Tratistic & 0.05 \\
Critical Value & Prob.** \\
\hline None $*$ & 0.468950 & 260.5865 & 69.81889 & 0.0000 \\
At most $1 *$ & 0.442470 & 186.5373 & 47.85613 & 0.0000 \\
At most $2 *$ & 0.366484 & 118.1814 & 29.79707 & 0.0000 \\
At most $3 *$ & 0.314515 & 64.77446 & 15.49471 & 0.0000 \\
At most $4 *$ & 0.161381 & 20.59188 & 3.841466 & 0.0000 \\
\hline
\end{tabular}

Sumber: Data diolah, 2020

Setelah dilakukan uji kointegrasi, dan didapatai bahwa model VECM adalah model yang dianggap tepat. Maka kemudian dilakukan estimasi model VECM. Hasil selengkapnya dari model VECM dapat diketahui dari tabel 6. Hasil menunjukkan bahwa pada model VECM pada tabel 6, diketahui bahwa secara umum model VECM pada kondisi data $1^{\text {st }}$ difference lag 1 , terbagi atas dua bagian, bagian atau bagian pertama merupakan hubungan variabel dalam jangka panjang, smentara pada bagian kedua (bawah) merupakan hubungan jangka pendek pada variabel. Pada bagian pertama, hubungan jangka panjang, variabel inflasi, kurs dan jumlah uang yang beredar (JUB) yang mampu mempengaruhi secara signifikan terhadap indeks harga JII. Pada variabel inflasi, angka koefisien menunjukkan angka sebesar $-28,10053$, artinya apabila terjadi kenaikan pada inflasi sebesar 1\% maka akan berdampak pada penurunan harga indeks JII sebesar 28,10053 .

\section{Tabel 6}

\section{Model VECM}

\begin{tabular}{cc}
\hline Cointegrating Eq: & CointEq1 \\
\hline $\mathrm{D}(\mathrm{JII}(-1))$ & 1.000000 \\
$\mathrm{D}(\mathrm{INFLASI}(-1))$ & -28.10053
\end{tabular}




\begin{tabular}{|c|c|c|c|c|c|}
\hline & $\begin{array}{c}(6.20807) \\
{[-4.52646]}\end{array}$ & & & & \\
\hline $\mathrm{D}(\mathrm{BIRATE}(-1))$ & $\begin{array}{c}-18.60084 \\
(18.8323) \\
{[-0.98771]}\end{array}$ & & & & \\
\hline $\mathrm{D}(\mathrm{KURS}(-1))$ & $\begin{array}{c}0.115987 \\
(0.01814) \\
{[6.39354]}\end{array}$ & & & & \\
\hline $\mathrm{D}(\mathrm{JUB}(-1))$ & $\begin{array}{c}-0.354054 \\
(0.07135) \\
{[-4.96190]}\end{array}$ & & & & \\
\hline $\mathrm{C}$ & 4.213522 & & & & \\
\hline R-squared & 0.407073 & 0.184682 & 0.219789 & 0.217964 & 0.378233 \\
\hline Adj. R-squared & 0.374732 & 0.140210 & 0.177232 & 0.175307 & 0.344319 \\
\hline Sum sq. resids & 85453.41 & 47.11618 & 3.998580 & 6287036. & 697222.6 \\
\hline S.E. equation & 27.87201 & 0.654468 & 0.190659 & 239.0708 & 79.61399 \\
\hline F-statistic & 12.58672 & 4.152782 & 5.164594 & 5.109742 & 11.15255 \\
\hline Log likelihood & -551.7386 & -112.8067 & 31.49392 & -803.1876 & -674.5379 \\
\hline Akaike AIC & 9.551088 & 2.047978 & -0.418700 & 13.84936 & 11.65022 \\
\hline Schwarz SC & 9.716346 & 2.213236 & -0.253441 & 14.01462 & 11.81548 \\
\hline Mean dependent & 0.006120 & 0.000855 & 0.000000 & 1.053077 & 0.530966 \\
\hline S.D. dependent & 35.24805 & 0.705818 & 0.210193 & 263.2574 & 98.32027 \\
\hline
\end{tabular}

Sumber: Data diolah, 2020

Begitu pula pada koefisien pada kurs, angka koefisien sebesar 0,115987, hal ini mengandung arti bahwa ketika terjadi kenaikan kurs sebesar 1\% maka akan berdampak pada kenaikan harga indeks JII sebesar 0,115987. Sementara pada koefisien jumlah uang yang beredar menunjukkan angka sebesar -0,354054. Hal ini mengandung makna bahwa apabila terjadi kenaikan jumlah uang sebesar $1 \%$ juga kana berdampak pada penurunan harga indeks JII sebesar 0,354054.

Sementara pada bagian bawah dari tabel 6 menunjukkan hasil estimasi jangka pendek antar variabel. hanya variabel inflasi dan kurs yang berpengaruh secara signifikan terhadap indeks harga JII. Dalam jangka pendek, kenaikan inflasi satu tahun sebelumnya sebesar 1\% akan berpengaruh sebesar -13.30787 pada indeks harga JII. Begitu pula terjadinya kenaikan pada kurs sebesar 1\% pada 
periode tahun sebelumnya, akan berdampak pada naiknya indeks harga JII sebesar 0.019682 .

Pada tabel 6 juga dapat dilihat bahwa hasil uji R2 menunjukkan angka Adjusted $R$ Square sebesar 0.374732, artinya kemampuan dari variabel inflasi, BI rate, kurs dan JUB dalam menjelaskan variasi naik turunnya indeks harga JII sebesar $37,47 \%$. Artinya sebesar $62,53 \%$ dipengaruhi oleh faktor lain di luar variabel penelitian ini.

Penggunaan uji kausalitas Granger diperlukan untuk dapat melihat apakah dari masing-masing variabel dapat berperan menjadi variabel dependen antara satu variabel dengan variabel yang lain, hasil uji kausalitas dapat dilihat pada tabel 7. Pada tabel 7, dengan memperhatikan nilai probabilitas diketahui bahwa apabila nilai probabilitas kurang dari 0,05 maka terjadi hubungan kausalitas antar variabel tersebut, dan sebaliknya apabila nilai probabilitas lebih besar dari 0,05 maka tidak terjadi hubungan kausalitas.

Hasil menunjukkan bahwa pada hanya variabel JII berpengaruh terhadap kurs, variabel JUB juga juga berpengaruh terhadap indeks JII. Pada variabel yang lain, hasil uji kausalitas juga menunjukkan kurs berpengaruh terhadap inflasi.

Tabel 7 Hasil Uji kausalitas

\begin{tabular}{lccc}
\hline Null Hypothesis: & Obs & F-Statistic & Prob. \\
\hline INFLASI does not Granger Cause JII & 119 & 1.14735 & 0.2863 \\
JII does not Granger Cause INFLASI & & 0.13090 & 0.7182 \\
\hline BIRATE does not Granger Cause JII & 119 & 0.00173 & 0.9669
\end{tabular}




\begin{tabular}{llll} 
JII does not Granger Cause BIRATE & 1.58852 & 0.2101 \\
\hline KURS does not Granger Cause JII & 119 & 3.41996 & 0.0670 \\
JII does not Granger Cause KURS & 119 & 6.16755 & 0.0144 \\
\hline JUB does not Granger Cause JII & & 1.40422 & 0.0318 \\
JII does not Granger Cause JUB & 119 & 0.00029 & 0.2384 \\
\hline BIRATE does not Granger Cause INFLASI & & 16.7254 & 0.9864 \\
INFLASI does not Granger Cause BIRATE & 119 & 4.31649 & $8 . E-05$ \\
\hline KURS does not Granger Cause INFLASI & & 6.13995 & 0.0400 \\
INFLASI does not Granger Cause KURS & 119 & 3.84755 & 0.0147 \\
\hline JUB does not Granger Cause INFLASI & & 0.03178 & 0.0522 \\
INFLASI does not Granger Cause JUB & 119 & 1.38840 & 0.8588 \\
\hline KURS does not Granger Cause BIRATE & & 0.41293 & 0.2411 \\
BIRATE does not Granger Cause KURS & 119 & 1.17979 & 0.5218 \\
\hline JUB does not Granger Cause BIRATE & & 0.01687 & 0.2797 \\
BIRATE does not Granger Cause JUB & 119 & 2.09412 & 0.8969 \\
\hline JUB does not Granger Cause KURS & & 0.10745 & 0.1506 \\
KURS does not Granger Cause JUB & &
\end{tabular}

Sumber: Data diolah, 2020

Pada IRF (Impulse Response Function) dilakukan dengan tujuan untuk melihat/memperkirakan efek terjadinya guncangan yang disebabkan salah satu variabel terhadap variabel lainnya. Hasil peramalan dengan menggunakan IRF dapat dilihat pada gambar 1 . 

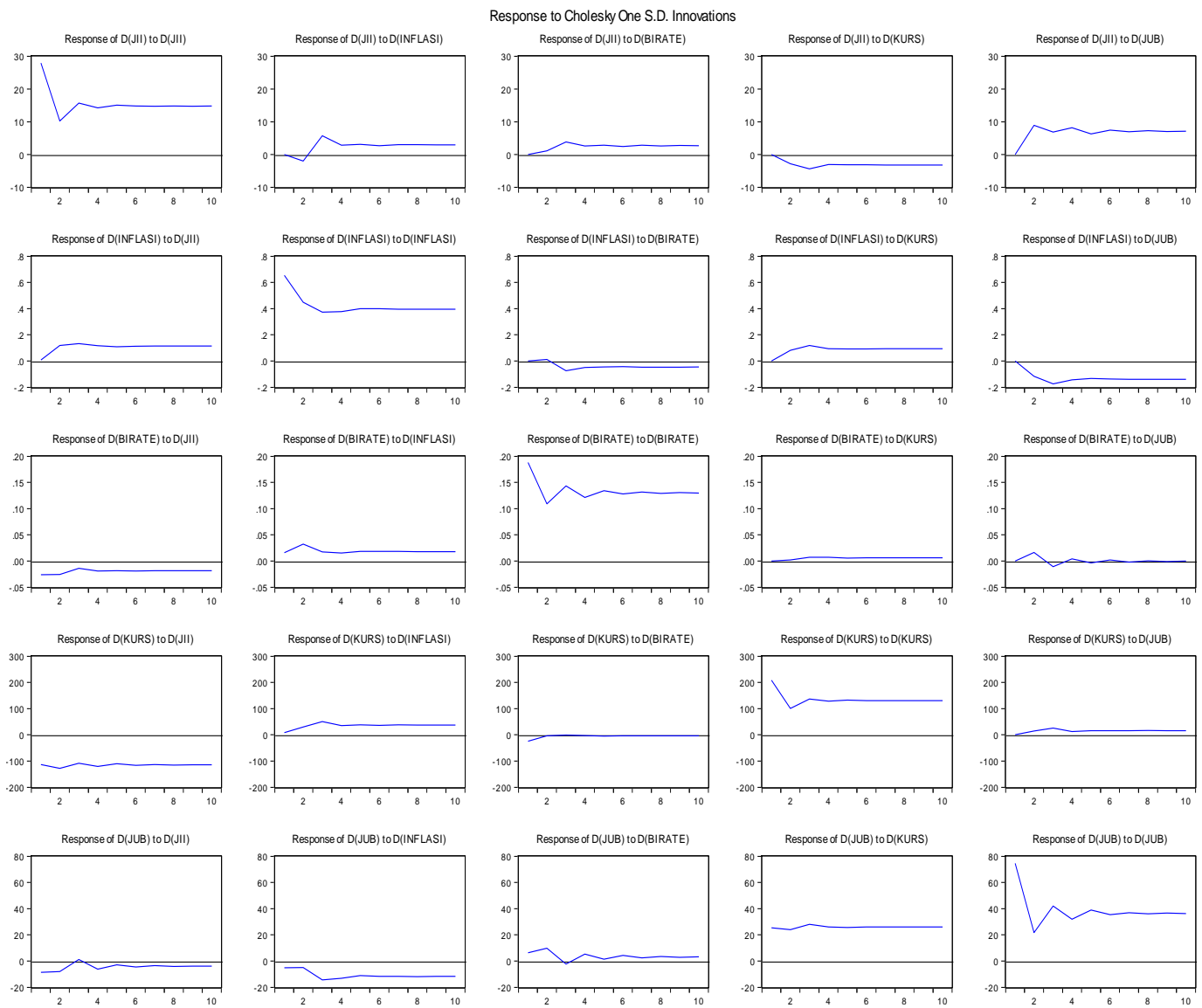

\section{Gambar 1. Hasil peramalan menggunakan IRF}

Berdasarkan hasil IRF pada gambar 1, diketahui pada baris pertama menjelaskan analisis IRF dari JII terhadap guncangan pada dirinya sendiri, inflasi, BI rate, kurs dan JUB yang terjadi untuk 10 bulan kedepan, penjelasannya adalah sebagai berikut: Respon JII terhadap guncangan dirinya sendiri pada bulan pertama mengalami penurunan hingga bulan kedua, baru memasuki bulan ketiga mengalami kenaikan, sedikit mengalami penurunan pada bulan ke empat dan relative stabil pada bulan ke lima hingga bulan kesepuluh. Respon JII terhadap guncangan pada inflasi pada bulan pertama hingga bulan kedua JII mengalami penurunan, dan kemudian mengalami kenaikan hingga bulan ketiga, kemudian mengalami penurunan kembali pada bulan keempat dan cenderung mulai stabil 
saat memasuki bulan kelima sampai dengan bulan kesepeluh.

Respon JII terhadap guncangan pada BI rate pada bulan pertama cenderung tidak terjadi perubahan, baru saat memasuki bulan kedua, sedikit mengalami kenaikan hingga bulan ketiga baru mengalami penurunan dan saat memasuki bulan keempat sudah cenderung stabil hingga bulan kesepuluh. Respon JII terhadap guncangan kurs pada awal tidak terjadi perubahan, hingga pertengahan bulan pertama terjadi penurunan hingga pertengahan bulan ketiga, dan sedikit mengalami kenaikan dibulan keempat dan terjadi kestabilan saat memasuki bulan kelima hingga bulan kesepuluh. Respon JII terhadap guncangan JUB pada bulan pertama mengalami kenaikan tajam hingga bulan ketiga, kemudian sedikit mengalami penurunan dan naik kembali di bulan keempat baru saat memasuki bulan keenam cenderung stabil hingga bulan kesepuluh.

Selanjutnya hasil IRF pada gambar baris kedua menjelaskan anilisis IRF dari inflasi terhadap guncangan pada JII, dirinya sendiri, BI rate, kurs, dan JUB yang terjadi untuk 10 bulan kedepan, penjelasannya adalah sebagai berikut: Respon inflasi terhadap guncangan JII pada awal bulan inflasi mengalami kenaikan sampai bulan kedua, dan memasuki bulan ketiga dan seterusnya inflasi cenderung stabil walaupun masih diatas keadaan awal (naik). Respon inflasi terhadap guncangan pada dirinya sendiri pada awal bulan inflasi terus mengalami penurunan yang cukup tajam dan memasuki bulan kedua, cenderung mulai melandai walaupun masih tturun hingga pada bulan keempat sedikit mengalami kenaikan serta bulan kelima dan seterunya mengalami kestabilan. Respon inflasi terhadap guncangan pada BI rate pada awal bulan hingga bulan kedua cenderung 
tidak terjadi pergeseran, tetapi memsauki bulan ke tiga inflasi mengalami penurunan dan bulan keempat sedikit naik kembali hingga bulan kelima dan seterusnya inflasi mengalami kestabilan walaupun kurvanya masih berada dibawah keaadaan awal (turun).

Respon inflasi terhadap guncangan kurs pada awal bulan inflasi cenderung mengalami kenaikan tetapi tidak signifikan hingga memasuki bulan keempan sedikit menurun dan pada bula ke lima dan seterusnya mengalami kestabilan hingga bulan kesepuluh. Respon inflasi terhadap guncangan JUB pada bulan pertama cenderung turun hingga bulan ketiga, sedikit mengalami kenaikan dan cenderung mulai stabil di bulan keempat, walaupun kondisinya masih dibawah (turun) bila dibandingkan pada kondisi awal.

Selanjutnya hasil IRF pada gambar baris ketiga menjelaskan anilisis IRF dari BI rate terhadap guncangan pada JII, BI rate, dirinya sendiri, kurs, dan JUB yang terjadi untuk 10 bulan kedepan, penjelasannya adalah sebagai berikut: Respon BI rate terhadap guncangan JII pada awal bulan BI rate turun dan relative stabil, walaupun pada bulan ketiga ada kecenderungan sedikit mengalami kenaikan dan kemabli stabil pada bulan keempat dan setreusnya. Respon BI rate terhadap guncangan pada inflasi pada bulan pertama BI rate terjadi kenaikan hingga bulan kedua, dan kembali turun pada bulan ketiga dan memasuki bulan keempat sudah mengalami kestabilan hingga bulan kesepuluh. Respon BI rate terhadap guncangan pada dirinya sendiri pada awal bulan hingga bulan kedua terjadi penurunan yang cukup tinggi, dan bulan ketiga naik hingga memasuki bulan keempat kembalia turun, memasuki bulan kelima BI rate cenderung stabil 
hingga bulan kesepuluh.

Respon BI rate terhadap guncangan kurs, dari awal bulan sedikit sekali mengalami kenaikan tetapi memasuki bulan kedua BI rate cenderung stabil hingga bulan kesepuluh. Respon BI rate terhadap guncangan JUB, pada bulan pertama terdapat kenaikan pada BI rate dan terjadi penurunan kembali pada bulan kedua, kemudian ada kenaikan sedikit dibulan ketiga dan cenderung mulai stabil pada bulan keempat dan seterusnya.

Selanjutnya hasil IRF pada gambar baris keempat menjelaskan anilisis IRF dari kurs terhadap guncangan pada JII, BI rate, dirinya sendiri, dan JUB yang terjadi untuk 10 bulan kedepan, penjelasannya adalah sebagai berikut: Respon kurs terhadap guncangan JII pada bulan pertama ada kecenderungan turun dan memasuki bulan kedua ada kenaikan pada kurs, serta pada bulan kelima sudah cenderung mengalami kestabilan. Respon kurs terhadap guncangan pada inflasi pawal bulan terjadi kenaikan dan memasuki bulan ketiga sedikit mengalami penurunan dan memasuki bulan keempat sudah mengalami kestabilan hingga bulan kesepuluh.

Respon kurs terhadap guncangan pada BI rate pada awal bulan pertama ada kecenderungan naik walaupun tidak terlalu signifikan, tetapi bulan kedua dan seterusnya hingga bulan kesepuluh terjadi kestabilan pada kurs. Selanjutnya hasil IRF pada gambar baris kelima menjelaskan anilisis IRF dari JUB terhadap guncangan pada JII, BI rate, kurs, dan dirinya sendiri yang terjadi untuk 10 bulan kedepan, penjelasannya adalah sebagai berikut Respon JUB terhadap guncangan JII pada bulan pertama, tidak terjadi perubahan dampak, hingga memasuki bulan 
kedua terjadi kenaikan tetapi bulan ketiga turun kembali, baru ketika memasuki bulan kelima dan seterusnya cenderung mengalami kestabilan. Respon JUB terhadap guncangan pada inflasi, pada bulan pertama cenderung stabil, dan bulan kedua mengalami penurunan serta memasuki bulan ketiga sudah stabil kembali walaupun kondisinya masih dibawah keadaan awal.

Sementara VD (Variance Decompotition) digunakan untuk mengetahui nilai seberapa besar kontribusi pada tiap periode baik dari variabel itu sendiri maupun variabel yang lain.

Tabel 8

Variance Decomposition of D(JII):

\begin{tabular}{ccccccc}
\hline Period & S.E. & D(JII) & D(INFLASI) & D(BIRATE) & D(KURS) & D(JUB) \\
\hline \hline 1 & 27.87201 & 100.0000 & 0.000000 & 0.000000 & 0.000000 & 0.000000 \\
2 & 31.19567 & 90.44611 & 0.407622 & 0.121355 & 0.834374 & 8.190536 \\
3 & 36.51182 & 84.46764 & 2.765247 & 1.181700 & 2.052175 & 9.533238 \\
4 & 40.30972 & 81.68750 & 2.749253 & 1.378135 & 2.271776 & 11.91334 \\
5 & 43.79985 & 81.01421 & 2.815881 & 1.575307 & 2.451885 & 12.14271 \\
6 & 47.06287 & 80.02267 & 2.768465 & 1.630231 & 2.580447 & 12.99818 \\
7 & 50.06999 & 79.34072 & 2.807604 & 1.751875 & 2.706837 & 13.39297 \\
8 & 52.95092 & 78.74018 & 2.822236 & 1.806192 & 2.795349 & 13.83604 \\
9 & 55.65307 & 78.30726 & 2.835375 & 1.872206 & 2.868195 & 14.11696 \\
10 & 58.24542 & 77.93113 & 2.843496 & 1.912574 & 2.927350 & 14.38545 \\
\hline \hline
\end{tabular}

Sumber: Data diolah, 2020

Pada tabel 8 dapat diketahui bahwa hasil estimasi VD menunjukkan bahwa kontribusi yang terjadi pada variabel JII, pada periode pertama variabel JII berkontribusi sebesar 100\%, artinya variabel yang lain belum ikut mempengaruhi. Sementara pada periode kedua variabel JII berkontribusi sebesar 90,44\% diikuti variabel inflasi sebesar $0,4 \%$, BI rate sebesar $0,12 \%$, kurs sebesar $0,83 \%$ dan JUB sebesar $8,19 \%$. Seiring perubahan pada tiap periode kontribusi yang diberikan oleh variabel JII sendiri semakin lama semkin menurun dan variabel yang lain 
semakin naik. Perubahan ini terjadi hingga pada periode kesepuluh variabel JII berkontribusi sebesar 77,93\%, semenatara inflasi sebesar $2,84 \%$, BI rate $1,91 \%$, kurs $2,92 \%$ dan JUB sebesar 14,38\%.

Tabel 9

Variance Decomposition of D(INFLASI):

\begin{tabular}{ccccccc}
\hline Period & S.E. & D(JII) & D(INFLASI) & D(BIRATE) & D(KURS) & D(JUB) \\
\hline \hline 1 & 0.654468 & 0.017444 & 99.98256 & 0.000000 & 0.000000 & 0.000000 \\
2 & 0.814930 & 2.148637 & 94.75098 & 0.022893 & 1.003327 & 2.074163 \\
3 & 0.933075 & 3.644601 & 88.20522 & 0.649991 & 2.393885 & 5.106300 \\
4 & 1.028337 & 4.290190 & 85.98320 & 0.768027 & 2.813433 & 6.145151 \\
5 & 1.121555 & 4.556320 & 85.01424 & 0.814542 & 3.024139 & 6.590758 \\
6 & 1.207997 & 4.803870 & 84.19320 & 0.832118 & 3.189254 & 6.981559 \\
7 & 1.288136 & 5.010432 & 83.46665 & 0.864722 & 3.341798 & 7.316400 \\
8 & 1.363315 & 5.170312 & 82.90320 & 0.887805 & 3.456670 & 7.582013 \\
9 & 1.434652 & 5.295425 & 82.46688 & 0.906372 & 3.546975 & 7.784353 \\
10 & 1.502652 & 5.398094 & 82.10763 & 0.920466 & 3.620857 & 7.952954 \\
\hline \hline
\end{tabular}

Sumber: Data diolah, 2020

Tabel 10

Variance Decomposition of D(BIRATE):

\begin{tabular}{ccccccc}
\hline Period & S.E. & D(JII) & D(INFLASI) & D(BIRATE) & D(KURS) & D(JUB) \\
\hline \hline 1 & 0.190659 & 1.878818 & 0.672233 & 97.44895 & 0.000000 & 0.000000 \\
2 & 0.223989 & 2.684098 & 2.537427 & 94.23895 & 0.008943 & 0.530577 \\
3 & 0.267227 & 2.160917 & 2.212328 & 95.01078 & 0.076595 & 0.539376 \\
4 & 0.294657 & 2.201479 & 2.088874 & 95.12596 & 0.123296 & 0.460393 \\
5 & 0.324815 & 2.130779 & 2.032131 & 95.31519 & 0.129272 & 0.392626 \\
6 & 0.350103 & 2.122977 & 2.017487 & 95.37792 & 0.140120 & 0.341496 \\
7 & 0.374889 & 2.097968 & 1.994059 & 95.46090 & 0.146748 & 0.300322 \\
8 & 0.397389 & 2.082739 & 1.976531 & 95.51984 & 0.153552 & 0.267336 \\
9 & 0.419092 & 2.070699 & 1.960735 & 95.56962 & 0.158064 & 0.240884 \\
10 & 0.439505 & 2.060546 & 1.950069 & 95.60833 & 0.162015 & 0.219043 \\
\hline \hline
\end{tabular}

Sumber: Data diolah, 2020

Pada tabel 10 dapat diketahui bahwa kontribusi variabel $\mathrm{BI}$ rate berdasarkan estimasi VD, hasil menunjukkan bahwa pada periode pertama kontribusi variabel JII sebesar $1,87 \%$, sementara infllasi $0,67 \%$, BI rate sendiri 
sebesar 97,44 dan untuk kurs dan JUB masing-masing tidak memberikan kontribusi. Hingga pada periode kesepuluh, variabel JII berkontribusi sebesar $2,06 \%$ terhadap BI rate, inflasi sebesar $1,95 \%$, BI rate sendiri sebesar 95,60\%, kurs dan JUB sebesar 0,16\% dan 0,21\%.

Pada tabel 11 dapat dilihat bahwa kontribusi pembentukan variabel kurs berdasarkan estimasi VD. Pada periode pertama variabel JII memberikan kontribusi sebesar 22,60\%, sementara inflasi sebesar $0,12 \%$. Variabel BI rate sebesar $1,01 \%$, kurs $76,25 \%$ dan JUB sebesar $0 \%$. Sementara pada periode kesepuluh, kontribusi pembentukan kurs dari variabel JII sebesar 39,1\%, inflasi $3,82 \%$, BI rate sebesar $0,20 \%$ dan kurs sendiri sebesar 56,07\% JUB sebesar $0,75 \%$

Tabel 11

Variance Decomposition of D(KURS):

\begin{tabular}{ccccccc}
\hline Period & S.E. & D(JII) & D(INFLASI) & D(BIRATE) & D(KURS) & D(JUB) \\
\hline \hline 1 & 239.0708 & 22.60684 & 0.122521 & 1.017874 & 76.25277 & 0.000000 \\
2 & 291.3982 & 34.59170 & 1.109261 & 0.705212 & 63.34157 & 0.252262 \\
3 & 344.1386 & 34.62041 & 2.908292 & 0.505944 & 61.23198 & 0.733370 \\
4 & 388.3017 & 36.82898 & 3.086105 & 0.404043 & 58.99103 & 0.689848 \\
5 & 426.8393 & 37.16723 & 3.366540 & 0.349536 & 58.40591 & 0.710790 \\
6 & 462.9995 & 37.93509 & 3.460937 & 0.303868 & 57.57765 & 0.722452 \\
7 & 496.1244 & 38.30958 & 3.611137 & 0.271757 & 57.07190 & 0.735620 \\
8 & 527.3721 & 38.66514 & 3.693599 & 0.246008 & 56.64982 & 0.745438 \\
9 & 556.7716 & 38.91936 & 3.769717 & 0.226212 & 56.33385 & 0.750860 \\
10 & 584.7309 & 39.13643 & 3.826238 & 0.209908 & 56.07055 & 0.756875 \\
\hline \hline
\end{tabular}

Sumber: Data diolah, 2020

Pada tabel 12 berdasarkan estimasi VD dapat diketahui bahwa kontribusi pembentukan variabel JUB pada periode pertama, variabel JII memberikan kontribusi sebesar $1,17 \%$, inflasi sebsar $0,41 \%$, BI rate sebesar $0,61 \%$, kurs sebesar 10,18\% dan JUB sendiri sebesar 87,60\%. Periode kesepuluh pada tabel 10 dapat diketahui bahwa kontribusi pembentukan JUB dari variabel JII sebesar 
$1,05 \%$ (menurun) dan inflasi sebesar 4,91\%, BI rate $0,88 \%$, kurs sebesar $26,43 \%$ dan JUB sendiri sebesar 66,70\%.

Tabel 12

Variance Decomposition of D(JUB):

\begin{tabular}{ccccccc}
\hline Period & S.E. & D(JII) & D(INFLASI) & D(BIRATE) & D(KURS) & D(JUB) \\
\hline \hline 1 & 79.61399 & 1.178369 & 0.415906 & 0.613946 & 10.18836 & 87.60342 \\
2 & 86.99220 & 1.840390 & 0.678416 & 1.798990 & 16.05657 & 79.62563 \\
3 & 101.5883 & 1.364297 & 2.503972 & 1.366439 & 19.34890 & 75.41639 \\
4 & 110.7246 & 1.454123 & 3.521984 & 1.375819 & 21.80849 & 71.83958 \\
5 & 120.6732 & 1.282801 & 3.810824 & 1.172659 & 22.85415 & 70.87957 \\
6 & 129.0708 & 1.247517 & 4.157078 & 1.132726 & 24.01394 & 69.44874 \\
7 & 137.2860 & 1.169207 & 4.395031 & 1.030606 & 24.79111 & 68.61405 \\
8 & 144.8676 & 1.127768 & 4.618511 & 0.980090 & 25.47469 & 67.79894 \\
9 & 152.1653 & 1.085828 & 4.779053 & 0.922410 & 25.98779 & 67.22492 \\
10 & 159.0761 & 1.054838 & 4.919182 & 0.883402 & 26.43393 & 66.70865 \\
\hline \hline
\end{tabular}

Sumber: Data diolah, 2020

Hasil penelitian ini menunjukkan bahwa nilai tukar rupiah terhadap dolar Amerika mempunyai dampak yang signifikan terhadap fluktuasi indeks harga saham JII. Selain itu para investor akan cenderung berpikir rasional, kenaikan kurs mata uang akan memberikan efek langsung terhadap nilai indeks JII. Secara teori kenaikan nilai tukar dapat meningkatkan harga bahan baku dan berdampak pada meningkatnya biaya produksi sehingga berpengaruh terhadap berkurangnya keuntungan yang didapatkan para pelaku usaha. Penelitian ini senada dengan hasil penelitian (Nofiatin, 2013), (Utami \& Herlambang, 2017). Dan hasil ini berbeda dengan penelitian (Sunardi \& Ula, 2017), (Ridha \& Harmaini, 2019).

Hasil penelitian ini menunjukkan bahwa variabel inflasi dapat secara langsung berpengaruh terhadap indeks harga saham JII. Kenaikan inflasi dalam jangka pendek cenderung direspon secara cepat terhadap penentuan instrument dalam berinvestasi. Naiknya inflasi menjadi sinyal buruk bagi investor untuk 
menanam modal yang mereka miliki dalam kegiatan pasar modal. Artinya mereka akan cenderung bermain aman dengan menaruh uangnya pada sektor perbankkan yang memberikan keuntungan yang lebih.

Naiknya inflasi akan berdampak pada kenaikan kenikan setiap komoditi yang ada. Hal ini berdampak pada menurunnya daya beli masyarakat. Penurunan daya beli akan berpengaruh terhadap permintaan barang dan jasa. Penelitian ini mempunyai hasil yang berbeda dari (Astuti dkk., 2013), (Nofiatin, 2013), (Suriyani \& Sudiartha, 2018), (Utami \& Herlambang, 2017), dan sejalan dengan (Sunardi \& Ula, 2017), (Ridha \& Harmaini, 2019).

Hasil penelitian ini menunjukkan bahwa kenaikan jumlah uang yang beredar di masyarakat tidak berpengaruh terhadap kenaikan indeks harga saham JII. Kenaikan jumlah uang yang beredar dalam jangka pendek merupakan bukti adanya peningkatan pendapatan yang ada di masyarakat. Naiknya pendapatan merupakan bukti atas naiknya daya beli, artinya kenaiakan daya beli juga akan berdampak pada meningkatnya permintaan akan barang dan jasa sektar bergairahnya pasar di sektor riil. Walaupun demikian untuk kurun waktu yang relatif lama kenaikan jumlah uang yang beredar tanpa diimbangi dengan adanya peningkatan produksi barang dan jasa akan berdampak pada naiknya inflasi di masyarakat.

Hal ini menunjukkan bahwa para pelaku usaha mendapatkan peluang untuk meningkatkan investasinya pada sektor pasar modal. Dengan harapan pada tiap periode tertentu mereka akan mendapatkan keuntungan berupa deviden ataupun hanya sekedar keuntungan berupa margin harga jual dan beli pada jenis 
saham tersebut. Penelitian ini mempunyai hasil yang berbeda dengan penelitian (Nofiatin, 2013). Tetapi relatif sama dengan penelitian yang dilakukan (Mawardi, 2018), (Chotib \& Huda, 2019).

Hasil uji regresi menunjukkan bahwa naiknya suku bunga akan mendapatkan respon negatif dari para investor. Artinya investor akan berupaya untuk mengalihkan modal yang mereka miliki pada sektor keuangan yang relative lebih menguntungkan. Tetapi hasil ini menunjukkan bahwa respon negatif suku bunga terhadap harga saham JII tidak menunjukkan angka yang signifikan. Untuk periode penelitian dari tahun 2010 sampai dengan 2019 hasil menunjukkan bahwa tingkat suku bunga dianggap berada pada posisi yang relatif rendah.

Data menunjukkan bahwa nilai suku bunga dalam periode tersebut ratarata berada di angka $6 \%$. Nilai suku bunga yang demikian dianggap masih relatif kecil bagi para investor, kecenderungan ini menunjukkan bahwa mereka lebih memilih untuk bertahan dalam kegiatan pasar modal. Disi lain perubahan kebijakan bank sentral dalam hal ini bank Indonesia yang memberlakukan kebijakan suku bunga berupa BI-7 Day Repo rate juga ikut mempengaruhi intensitas pasar modal. Kebijakan tersebut akan dianggap sebagai kebijakan pasar keuangan yang cukup elastis. Penelitian ini mmepunyai hasil yang beda dengan (Astuti dkk., 2013), (Chotib \& Huda, 2019), (Utami \& Herlambang, 2017), . Tetapi sejalan dengan penelitian (Nofiatin, 2013), penelitian (Suriyani \& Sudiartha, 2018). 


\section{SIMPULAN DAN SARAN}

Hasil penelitian menunjukkan bahwa hubungan jangka panjang, variabel inflasi, kurs dan jumlah uang yang beredar (JUB) yang mampu mempengaruhi secara signifikan terhadap indeks harga JII. Hasil estimasi jangka pendek antar variabel. hanya variabel inflasi dan kurs yang berpengaruh secara signifikan terhadap indeks harga JII.

Penelitian berikutnya, perlu dilakukan pengujian kembali dengan menggunakan data dengan periode waktu yang berbeda, mengingat penelitian ini menggunakan data tahun 2010 s/d 2019. Selain itu dirasa perlu untuk menambahkan jumlah populasi yang lebih luas.

\section{REFERENSI}

Astuti, R., Prihatini, A. E., \& Susanta, H. (2013). Analisis pengaruh tingkat suku bunga (SBI), nilai tukar (kurs) Rupiah, inflasi, dan indeks bursa internasional terhadap IHSG (Studi pada IHSG di BEI periode 20082012). Jurnal Ilmu Administrasi Bisnis, 2(4), 136-145.

Chotib, E., \& Huda, N. (2019). Analisis Pengaruh Variabel Ekonomi Makro terhadap Indeks Saham Syariah Indonesia (ISSI) periode 2016-2019. JEBA (Journal of Economics and Business Aseanomics), 4(1).1-20.

Fathurrahman, A., \& Rusdi, F. (2019). Analisis Faktor-Faktor Yang Mempengaruhi Likuiditas Bank Syariah Di Indonesia Menggunakan Metode Vector Error Correction Model (Vecm). Al-Masraf: Jurnal Lembaga Keuangan dan Perbankan, 4(2), 117-126.

Geriadi, M. A. D., \& Wiksuana, I. G. B. (2017). Pengaruh Inflasi Terhadap Return Saham Pada Perusahaan Properti Dan Real Estate Yang Terdaftar Di Bursa Efek Indonesia (Risiko Sistematis Dan Profitabilitas Sebagai Variabel Mediasi). E-Jurnal Ekonomi Dan Bisnis Universitas Udayana, 9(1), 3435-3250.

Mawardi, A. (2018). Pengaruh Nilai Tukar, Tingkat Bunga, Inflasi, Dan Jumlah Uang Beredar Terhadap Indeks Harga Saham Sektor Keuangan Di Bursa Efek Indonesia (Bei) (Studi Kasus Pada Indek Harga Saham Sektor Keuangan Di Bei). Eqien: Jurnal Ekonomi dan Bisnis, 5(2), 1-19. 
Meirison, M. (2017). Bank Syari'ah Menghadapi Tantangan dan Harapan. AlMasraf: Jurnal Lembaga Keuangan dan Perbankan, 2(1), 73-83.

Nofiatin, I. (2013). Hubungan Inflasi, Suku Bunga, Produk Domestik Bruto, Nilai Tukar, Jumlah Uang Beredar, dan Indeks Harga Saham Gabungan (IHSG) Periode 2005-2011. Jurnal Aplikasi Manajemen, 11(2), 215-222.

Pradana, M. N. R. (2018). Pengaruh Likuiditas dan Variabel Eksternal Terhadap Non Performing Financing Pada Bank Syariah. Eksis: Jurnal Riset Ekonomi dan Bisnis, 13(2), 131-144.

Ridha, M. R., \& Harmaini, H. (2019). Pengaruh Inflasi, Bi Rate, Kurs Dan Indeks Dow Jones Industrial Average Terhadap Jakarta Islamic Index (Jii). Media Ekonomi, 25(2), 87-92.

Samuelson. (2004). Makro Ekonomi. PT. Media Global Edukasi.

Septifany, A. T. (2015). Analisis Pengaruh Inflasi, Tingkat Suku Bunga, Nilai Tukar Rupiah Dan Cadangan Devisa Terhadap Penanaman Modal Asing Di Indonesia (Studi Pada Bank Indonesia Periode Tahun 2006-2014). Jurnal Administrasi Bisnis, 25(2).1-28.

Sitinjak, N. D. (2016). Dampak Inflasi, Pertumbuhan Jumlah Pekerja, dan Pertumbuhan PDB per kapita Terhadap Penerimaan Pajak. Eksis: Jurnal Riset Ekonomi dan Bisnis, 11(2).10-30.

Sukirno, S. (2004). Makroekonomi teori pengantar. Jakarta: PT raja Grafindo persada.

Sunardi, N., \& Ula, L. N. R. (2017). Pengaruh BI Rate, Inflasi Dan Kurs Terhadap Indeks Harga Saham Gabungan (IHSG). Jurnal Sekuritas: Saham, Ekonomi, Keuangan dan Investasi, 1(2), 27-41.

Suriyani, N. K., \& Sudiartha, G. M. (2018). Pengaruh Tingkat Suku Bunga, Inflasi Dan Nilai Tukar Terhadap Return Saham Di Bursa Efek Indonesia. E-Jurnal Manajemen Universitas Udayana, 7(6).57-65.

Utami, A. T., \& Herlambang, L. (2017). Pengaruh Variabel Makro Ekonomi Terhadap Indeks Jakarta Islamic Index (JII) Periode Januari 2010 Hingga November 2015. Jurnal Ekonomi Syariah Teori dan Terapan, 3(1), 70-89. 